Original Research Paper

\title{
Pendidikan Bagi Masyarakat Kategori Marginal Kawasan Pariwisata: Aplikasi Pendidikan Berbasis Praktik Sosial
}

\author{
Sukardi $^{1}$, Wildan $^{1}$, Akhmad Sukri $^{3}$ \\ ${ }^{12}$ Fakultas Keguruan dan Ilmu Pendidikan \& Pascasarjana, Universitas Mataram \\ ${ }^{3}$ Pendidikan Biologi, Universitas Pendidikan Mandala Mataram
}

DOI: https://doi.org/10.29303/jpmpi.v3i2.462

Sitasi : Sukardi., Wildan., \& Sukri, A. (2020). Pendidikan Bagi Masyarakat Kategori Marginal Kawasan Pariwisata: Aplikasi Pendidikan Berbasis Praktik Sosial. Jurnal Pengabdian Magister Pendidikan IPA, 3(2)

Article history

Received: 30 Agustus 2020

Revised: 20 Oktober 2020

Accepted: 19 November 2020

*Corresponding Author:

Sukardi,

Fakultas

Keguruan dan Ilmu Pendidikan, Universitas Mataram, Indonesia.

Email:

sukardi@unram.ac.id

\begin{abstract}
Masyarakat marginal, seperti anak yang putus sekolah atau tidak melanjutkan studi karena berbagai faktor (ekonomi, geografi, sosial budaya) membutuhkan pendidikan alternatif bagi penyelesaiannya. Salah satunya adalah pendidikan berbasis praktik sosial, karena mengarah pada kecakapan hidup atau usaha mandiri dengan memanfaatkan potensi kawasan, seperti kawasan pariwisata/ekowisata. Faktanya, cukup banyak masyarakat kategori tersebut, seperti di Kawasan Pariwisata/Ekowisata Sekotong. Sebagai contoh, berdasarkann survei di Kawasan Sekotong Barat terdapat lebih dari 100 orang anak kategori dimaksud. Oleh karenanya, aplikasi pendidikan berbasis praktik sosial dalam bentuk Demonstration Plotting (Demplot) usaha ekonomi produktif ini menjadi instrumen intervensi bagi penyelesaian permasalahan masyarakat kategori dimaksud. Beberapa produk sebagai basis praktik sosial, yaitu: souvenir kerang laut, souvenir cangkang kerang, budidaya kepiting bakau, dan kuliner. Hasilkegiatan menunjukkan bahwa ketercapaian kompetensi minimal dalam memahami dan menciptakan produk usaha ekonomi produktif. Implikasinya adalah bahwa penguatan ekonomi masyarakat marginal melalui pendidikan berbasis praktik sosial dapat menjadi rujukan pada sektor pariwisata/ekowisata.
\end{abstract}

Keywords: Pendidikan, Masyarakat Marginal, Praktik Sosial

\section{Pendahuluan}

$P$ ariwisata Sekotong merupakan salah satu pusat atraksi wisata Kabupaten Lombok Barat dan Provinsi Nusa Tenggara Barat, dengan berbagai potensi destinasi ekowisata. Kawasan ini memiliki keunggulan potensial yang dapat dikembangkan dengan berbagai macam atraksi lainnya. Hasil kajian Wildan dan Sukardi (2017) menemukan bahwa kawasan e ini memiliki basis keunggulan dalam budidaya laut, kerajinan, jasa transportasi dan olah raga air. Permasalahannya adalah meskipun menjadi pusat pariwisata, penduduk lokal kawasan Sekotong tidak menjadi pemain dan pelaku utama pariwisata tersebut, karena rendahnya kualitas Sumber Daya Manusia (Wildan dkk., 2016). Mereka kurang mendapatkan peluang untuk berperan dalam kegiatan pariwisata. Efek ekonomi dari kegiatan pariwisata di kawasan Sekotong belum begitu berarti, karena rendahnya akses masyarakat terhadap pengelolaan pariwisata disamping kualitas sumber daya manusianya. 
Terkait dengan kualitas sumber daya manusia, paling tidak ada 2 bidang utama yang menjadi sosrotan sekaligus menjadi fokus, yaitu: bidang pendidikan dan ekonomi. Pada aspek pendidikan, kawasan ini dihadapkan pada masih rendahnya Angka Partisipasi Kasar (APK), Angka Partisipasi Murni (APM), Angka Partisipasi Sekolah (APS), anak putus sekolah atau tidak melanjutkan studi, penduduk bekerja tidak tamat SD, dan penduduk buta aksara. Sebagai contoh, untuk APM SMP/Sederajat sudah menyentuh 68,09, sedangkan tingkat Kabupaten lebih tinggi dengan nilai 84,50 (BPS Lobar, 2016). Data ini menujukkan bahwa tingkat partisipasi anak usia tersebut cukup baik, meskipun capaian APM masih rendah (BPS Lobar, 2015). Selanjutnya, hingga akhir tahun 2015, APS usia 7-12 tahun telah mencapai $97.35 \%$ di Kecamatan Sekotong dan 95,12\% tingkat Kabupaten (BPS Lobar, 2016).

Permasalahan bidang ekonomi di Kawasan ini dapat ditelusuri dari indikator, antara lain: jumlah penduduk miskin, garis kemiskinan, indeks kedalaman kemiskinan (P1), indeks keparahan kemiskinan (P2), struktur pekerjaan dan kualitas pekerjaan. Jumlah penduduk Miskin di Kabupaten Lombok Barat mencapai 17,42\% pada tahun 2014 (BPS Lobar, 2014), sementara hasil kajian Wildan dkk. (2016) di Sekotong menemukan lebih dari $30 \%$ penduduk tergolong miskin. Dilihat dari indikator indeks kedalaman kemiskinan (P1), di Sekotong Barat mencapai 3,0. Data ini lebih tinggi dibandingkan dengan rata-rata tingkat Kabupaten yang mencapai 2,91 (Pemda Lobar, 2016). Selanjutnya, dilihat dari indeks keparahan kemiskinan (P2) di Desa Sekotong Barat berdasarkan hasil kajian dan perhitungan Wildan dkk. (2016) menunjukkan capaian 0,86.

Menjadi pertanyaan adalah mengapa di kawasan yang memiliki potensi unggul (pusat pariwisata) justru penduduknya miskin? Mengapa pembangunan menjadi (seolah) mandul dan nampak tidak mampu menghadirkan output yang maksimal. Bicara output (kesejahteraan masyarakat), membawa penulis untuk menengok input (kualitas SDM). Sejauh manakah kualitas SDM selama ini sehingga kurang dapat mendongkrak output. Pertanyaan yang muncul dari sikap positif membuahkan logika untuk memperbaiki input tersebut. Atas dasar itu, kegiatan ini dilakukan untuk mempercepat pembangunan pada dua bidang dimaksud melalui aplikasi pendidikan berbasis praktik sosial.
Pendidikan berbasis sosial ini mengintegrasikan dengan dunia usaha, sehingga konten dan prosesnya berbasis keunggulan lokal. Pendidikan sebagai suatu praktik sosial senantiasa bersifat kontekstual. Pendidikan merupakan sesuatu yang dilakukan, diperbuat, dipraktikkan sesuai dengan tuntutan konteks yang melingkunginya. Seperti dinyatakan Gee (1996) bahwa pendidikan bukanlah "something we do with our heads " melainkan "something to do with social, institutional, and cultural relationships". Tujuannya, yaitu: (1) meningkatkan kompetensi kelompok sasaran kawasan Ekowisata Sekotong dalam menyiapkan dan mengembangkan pruduk dan jasa ekowisata; (2) meningkatkan skills kelompok sasaran dalam pengelolaan usaha ekonomi produktif termasuk pengelolaan dan pemasaran produk dan jasa ekowisata; dan (3) meningkatkan pendapatan dan daya beli masyarakat kelompok sasaran melalui pengembangan produk dan jasa ekowisata

\section{Metode}

Menanggapi permasalahan yang mengakibatkan kurangnya kemampuan guru fisika dalam melaksanakan proses pembelajaran fisika yang efektif dan efesien, maka permasalahan ini dapat diselesaikan dengan cara memberikan pelatihan Lesson Study kepada guru. Beberapa tahapan yang akan dilalui dalam penyelesaian masalah ini yaitu tahap persiapan, tahap pelaksanaan, dan tahap evaluasi (Doyan et al, 2018; Susilawati et al, 2019). Secara sederhana tahapan ini direpresentasikan dalam Gambar 1.

Berdasarkan tujuan kegiatan, maka metode yang digunakan dalam kegiatan pengabdian ini adalah kaji tindak partisipatif melalui Pelatihan dan Pembelajaran, Demonstration Plot (Demplot) dan dilakukan secara kolaboratif.

Pelatihan dan Pembelajaran

Kegiatan pelatihan dan pembelajaran dilakukan menggunakan pendekatan berbasis praktik sosial atau terintegrasi dengan usaha ekonomi produktif. Terintegrasi dimaksud adalah pembelajaran yang dilakukan sesuai dengan kebutuhan praktik, seperti misalnya membuat produk pariwisata. Pelatihan dan pembelajaran dalam bentuk kelompok/wadah belajar yang sekaligus menjadi Kelompok Usaha Bersama (KUBE). Untuk mengetahui capaian kegiatan, maka dilakukan penilaian terhadap proses dan produk yang dihasilkan dengan melibatkan 2 orang 


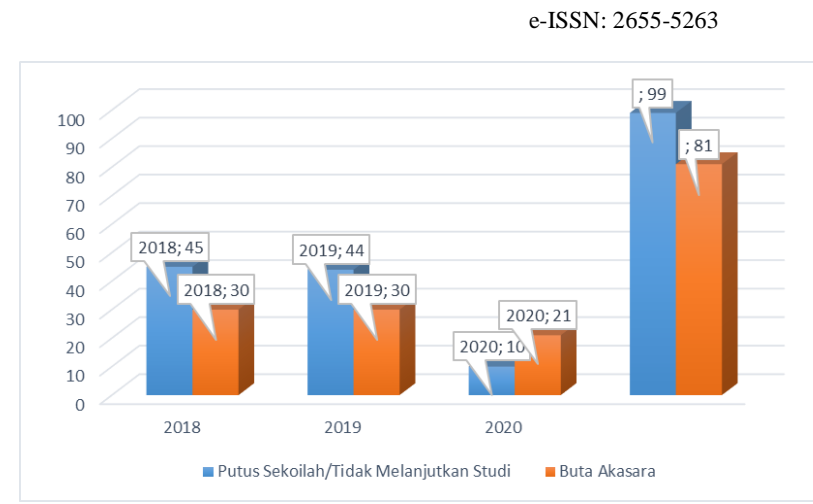

Gambar 01. Jumlah Sasaran Pemberdayaan Tahun 2018-2020

Berdasarkan kelompok produk atau jasa ekowisata yang menjadi sasaran pemberdayaan, maka sebagian besar berada pada KUBE kerajinan dan budidaya. Berdasarkan hal tersebut, maka fokus pemberdayaan terutama pendampingan juga banyak terkait dengan kedua produk tersebut. Selengkapnya divisualisasikan dalam Gambar 02.

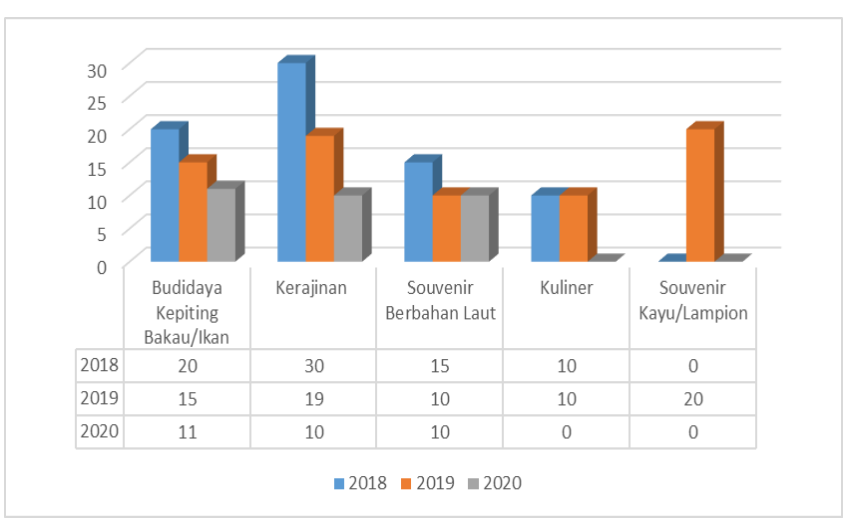

\section{Gambar 02. Jumlah Sasaran Pemberdayaan Berdasarkan Jenis Produk/Jasa Ekowisata Tahun 2018- 2020}

Hasil pelatihan atau pemberdayaan untuk masing-masing kelompok menunjukkan tingkat penguasaan materi pelatihan yang kategori baik. Pencapaian tertinggi pada kelompok budidaya dan kerajinan, sedangkan terendah pada kelompok kuliner (Gambar 03). 


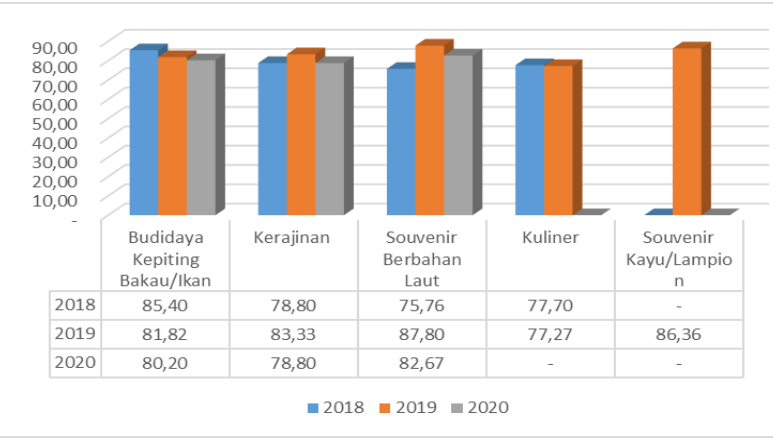

Gambar 03. Capaian Kompetensi

Kelompok Sasaran Berdasarkan

Jenis Produk/Ekowisata Tahun 20182020

Kelompok usaha bersama (KUBE) yang sudah dilatih kemudian didampingi. Pendampingan ini dilakukan selama kurang lebih 3 bulan setiap tahunnya dengan melibatkan tim, fasilitator, dan unsur pemerintah daerah. Selama proses pendampingan, hampir semua kelompok sudah pada memulai usaha dalam bentuk proses produksi. Kelompok kerajinan menunjukkan peningkatan yang signifikan dalam proses produksi yang dihasilkan. Demikian juga halnya dengan kelompok budidaya juga menunjukkan trend peningkatan. Meskipun demikian, kelompok buidaya mengalami fluktuatif selama proses budidaya dikarenakan iklim yang sering berubah. Hasil wawancara dengan masing-masing KUBE, menunjukkan trend peningkatan pendapatan. Selengkapnya divisualisasikan dalam Gambar 04 berikut.

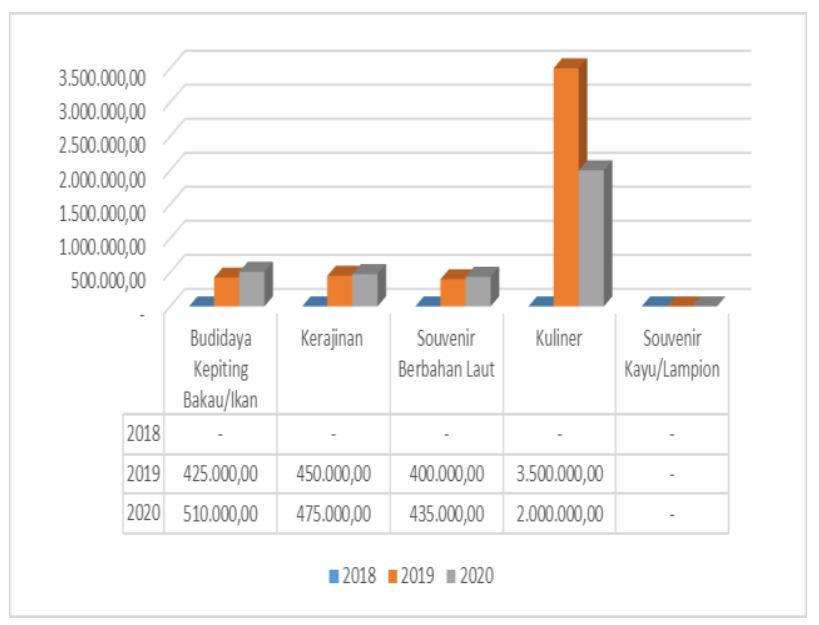

Gambar 04. Trend Peningkatan Pendapatan Kelompok Usaha Bersama Tahun 2018-2020

Kegiatan yang dikemas melalui pelatihan dan Demplot ini memberikan dampak cukup baik terhadap peningkatan kemampuan kelompok sasaran dalam dalam memulai usaha. Hal ini tidak lepas dari kegiatan yang menekankan pada aspek kemampuan melakukan, bukan hanya pada aspek pemahaman secara kognitif. Beberapa kelebihan kegiatan melalui pendekatan ini, antara lain: Pertama, menggunakan pendekatan andragogis dengan mengedepankan diskusi, brainstorming sehingga kelompok sasaran sebagai mitra yang aktif. Dalam pendekatan ini, semua kelompok sasaran diperlakukan sebagai orang dewasa yang memiliki kemampuan untuk belajar mandiri, orientasi pada pemecahan permasalahan sesuai kebutuhan, lebih matang untuk belajar, lebiah siap menerima karena untuk memenuhi kebutuhannya. Hal ini terjadi karena mereka memahami bahwa belajar untuk kebutuhan praktik kehidupannya termasuk praktik untuk bekerja mandiri. Model ini juga mengkonfirmasi temuan Wildan dan Sukardi (2020) bahwa model penguatan ekonomi masyarakat berbasisis praktik dengan menggunakan konten keunggulan lokal (produk ekowisata) teruji efektif terhadap pembentukan kompetensi wirausaha masyarakat lokal dalam menghasilkan produk ekowisata. Kedua, kegiatan ini berbasis pada praktik sosial. Praktik sosial terintegrasi dengan usaha ekonomi produktif. Pada kelompok pengrajin, maka materinya adalah tentang proses produksi kerajinan; kelompok budidaya ikan baronang, maka materi diarahkan tentang proses budidaya, dan seterusnya. Melalui proses belajar tersebut, tercipta pendidikan yang relevan secara budaya dan memberdayakan secara sosial (Degener, 2001). Hal ini mencerminkan bahwa proses learning is experiencing by exploration and society sebagaimana pendapat Knowles (1997), sehingga dalam pelatihan dan Demplot ini tidak lagi menggunakan teknik transformasional. Ketiga, proses partisipatif, kemitraan, dan kebersamaan dalam jkelompok belajar (Kelompok Usaha Bersama) dikedepankan selama proses pelatihan atau pembelajaran dan Demplot termasuk pendampingan. Hasilnya, peserta memahami materi dengan baik dan trampil menerapkan hasil pelatihan dalam kelompok usaha bersama. Partisipatif dan Kerjasama menjadi dasar penguatan 
pembelajaran berdasarkan teori rekonstruksi sosial. Kajian Sukardi dkk. (2014) dan Sukardi (2016; 2017) meneguhkan pentingnya pembelajaran secara interaktif dan partisipatif sebagai wujud implementasi pembelajaran berbasis rekonstruksi sosial. Hal ini menunjukkan bahwa proses pembelajaran yang baik dicirikan dengan kriteria tersebut, sehingga menghasilkan output (capain pembelajaran) yang baik pula.

\section{Kesimpulan}

Pendidikan berbasis praktik sosial menjadi instrumen yang cukup baik dalam melatih dan memberdayakan masyarakat sesuai dengan kebutuhan untuk hidup mandiri, seperti menyiapkan produk dan jasa ekowisata. Hasilnya menunjukkan bahwa semua kelompok belajar menguasai materi sesuai target di atas nilai 75. Di samping itu, peserta menunjukkan keantusiasan, aktif berpraktik, semangat, aktif dan disiplin mengikuti kegiatan. Hasil pembelajaran juga berdampak pada hasil praktik sosial, seperti adanya kelompok usaha bersama yang mampu menaikkan income per kapita masyarakat. Pendapatan dan produktivitas yang naik berimplikasi terhadap meningkatnya daya beli masyarakat sasaran. Dengan demikian, disimpulkan bahwa pembelajaran berbasis praktik sosial relevan digunakan bagi masyarkat kategori putus sekolah/tidak melanjutkan studi dan penduduk buta aksara.

\section{Ucapan Terima Kasih}

Ucapan terima kasih disampaikan kepada Kemneteria Riset dan teknologi/Badan Riset dan Inovasi Nasional beserta Universitas Mataram yang telah menfasilitasi kegiatan ini selama 3 tahun.

\section{Daftar Pustaka}

Badan Perencanaan Pembangunan Daerah/Bappeda Lobar. 2014. Indeks Pembangunan Manusia Kabupaten Lombok Barat 2014. Gerung; Kerjasama Bappeda Lombok Barat dengan BPS Lombok Barat

Badan Pusat Statistik Kabupaten Lombok Barat/BPS Lobar. 2015. Jumlah Siswa
SMP/MTs/Sederajat Usia 13-15 dan APM Per Kecamatan Tahun Ajaran 2014/2015. Gerung: BPS Kabupaten Lombok Barat.

Badan Pusat Statistik Kabupaten Lombok Barat/BPS Lobar. 2016. Lombok Barat dalam Angka 2015. Gerung: BPS Lombok Barat.

Degener, S.C. 2001. Making Sence of Critical Paedagogy in Adult Literacy Educational. Cambridge NCSALL.

Gee, J.P. 1990. Social Linguistics and Literacies. Briston, P.A: The Palmer Press.

Knowles, M.S. 1975. Self Directed Learning: $a$ Guide for Learners and Teachers. Chicago: Follet.

Pemerintah Daerah Kabupaten Lombok Barat/Bappeda Lobar. 2016. IPM Kabupaten/Kota di NTB Tahun 20102015. (Online) http://lombokbaratkab. go.id/wpcontent/uploads/2016/08/KabupatenLombok-Barat-Dalam-Angka-2016.pdf, diakses 12 November 2016.

Sukardi, S., Ismail, M., \& Suryanti, N. M. N. (2014). MODEL PENDIDIKAN KEWIRAUSAHAAN BERBASIS KETERAMPILAN LOKALBAGI ANAK PUTUS SEKOLAH PADA MASYARAKAT MARGINAL. Jurnal Cakrawala Pendidikan, 33(3).

Sukardi, S. (2016). DESAIN MODEL PRAKARYA DAN KEWIRAUSAHAAN BERBASIS EKONOMI KREATIF BERDIMENSI INDUSTRI KEUNGGULAN LOKAL. Jurnal Cakrawala Pendidikan, 35(1).

Sukardi, S. (2017). Efektivitas Model Prakarya dan Kewirausahaan Berbasis Ekonomi Kreatif Berdimensi Industri Keunggulan Lokal terhadap Keinovatifan Siswa. Jurnal Cakrawala Pendidikan, 36(2), 267-279.

Wildan, Sukardi, \& Syuaib, M.Z. 2016. Kajian Kelayakan dan Pengembangan Ekowisata Berbasis Kearifan Lokal di 
Lombok Barat Sebagai Tujuan Wisatawan Timur Tengah (Laporan Penelitian). Mataram: Lemlit Unram.

Wildan, W., \& Sukardi, S. (2017). Ecotourism Model Based on Social Capital (Halal Tourism) as the Strengthening Factor for the Economy of Lombok Community.

WILDAN, W., \& SUKARDI, S. (2020). Effectiveness of Ecotourism SectorBased Economic Strengthening Models for Local Community Entrepreneurial Competencies. Journal Environmental Management and Tourism, 11(2), 314-321. 